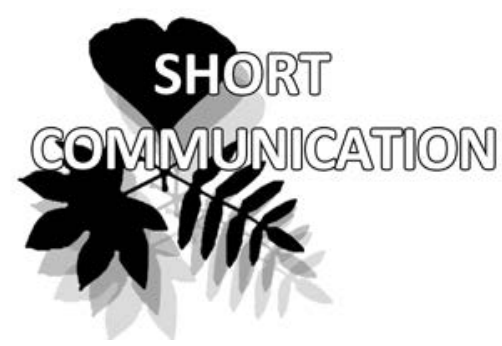

\title{
Caragana jubata (Pall.) Poir. (Fabaceae), distribution mapping of rare relict species
}

\author{
Alina G. Churiulina* \& Maxim V. Bocharnikov
}

Alina G. Churiulina *

e-mail: agchurylina@gmail.com

Maxim V. Bocharnikov

e-mail: maxim-msu-bg@mail.ru

Lomonosov Moscow State University, Faculty of Geography, Dept. of

Biogeography, Moscow, Russia

* corresponding authors

Manuscript received: 22.01.2019

Review completed: 10.09.2019

Accepted for publication: 10.10.2019

Published online: 13.10.2019

\begin{abstract}
A B S T R A C T
The spatial distribution mapping of rare plant species Caragana jubata (Pall.) Poir. was carried out. Caragana jubata is a relict of the Neogene Period. It is listed in the Red Data Books of 8 subjects of Russia. The determination of Caragana jubata distribution features and its mapping was made by the herbarium materials of the main collections of Russia (MWG, MW, LE, MHA, NS, NSK, TK), as well as literary data and online documents. The total list includes 475 locations of the species with georeferencing. Species occurrences, which we identified from herbarium collection MW, are included in the Global Biodiversity Information Facility (GBIF). It was observed a disjunction character of a wide pan-Asian spatial distribution of species. Different parts of its distribution related to the mountain regions: eastern part of the Tibetan Plateau, the northeast of the Himalayas, Central and Southern Tian Shan, Sayan Mountains, Stanovoy Highlands. The specific altitudinal and ecological features of species were determined in different regions.
\end{abstract}

K e y w o r d s : Caragana jubata, herbarium collections, rare species, relict, spatial distribution, GBIF

\section{P E 3 Ю M E}

Чурюлина А.Г., Бочарников М.В. Caragana jubata (Pall.) Poir. (Fabaсеае), картирование ареала редкого реликтового виАа. Проведено картографирование ареала редкого вила караганы гривастой (Caragana jubata (Pall.) Poir.). Caragana jubata является реликтом неогенового периода. Он включен в Красные книги 8 субъектов России. Определение особенностей пространственного распространения вида и его картографирование провеАено на основе гербарных материалов главных колмекций России (MWG, MW, LE, MHA, NS, NSK, TK), а также митературных данных и электронных ресурсов. Сводный список вкАючает 475 местонахождений виАа, имеющих точную географическую привязку. Аанные о находках вида, полученные из гербарной колмекции MW и не отображенные в информационной системе ранее, внесены в ГАобальный информационный фонА по биоразнообразию (GBIF). Определен дизъюнктивный характер обширного паназиатского ареала вила. Различные части ареала приходятся на горные регионы: восток Тибетского нагорья, северо-восток Гималаев, Центральный и Южный Тянь-Шань, Саяны, Становое нагорье. Аана характеристика экологических особенностей вида и его высотной приуроченности в разАичных регионах. КАючевые слова: Caragana jubata, гербарные колмекции, редкие виды, реликт, apeas, GBIF
The genus Caragana (Fabaceae), contains about 100 species distributed in northern Eurasia, from the Black Sea to southeastern Siberia, south to eastern and southwestern China, Nepal, Afghanistan and Turkmenistan (Zhang et al. 2009). The geographic distribution of Caragana is thought to be strongly related to the divisions of vegetation, climate, and natural landscape cover in China. There are species of this genus in a wide ecological space: from cold and arid regions, such as the Tibetan Plateau and Central Asia, to forest areas of eastern Asia, especially in northern China. In these regions, many Caragana species form dominant components of the natural vegetation. Structure changes of genus Caragana, dated to the early Miocene ca. 18 Mio, may be associated with the Himalayan Motion stage of Tibetan Plateau uplift (Zhang et al. 2016). Therefore, Caragana is regarded as a key taxon of flora for the inner regions of temperate Asia.

Komarov (1908) in creating the natural system of the Caragana Lam. defines 8 sections within the genus based on the morphological features of the most typical species. Caragana jubata (Pall.) Poir is attributed to the group "Jubatae", in which else only one species is included -C. tangutica Maxim. The species of this group are characterized by thin spines on the shoots, developing from leaf stalks, elongated wings of the corolla, with long ears at their basis and an almost blunt keel of the boat, with very short pedicels. 
Caragana jubata is a relict species of the Neogene Period (Baklanov \& Tulohonov 2010) with a pan-Asian type of spatial distribution (Verhozina 2013). The species is listed in the Red Data Books of the Republics of Altai, Buryatia, Sakha (Yakutia); Irkutsk, Magadan Regions; Khabarovsk, Krasnoyarsk and Trans Baikal Territories of the Russian Federation. According to the IUCN Red List Categories and Criteria, this species belongs to the following categories of status in different regions of the country:

1. Category $3(\mathrm{R})$, a rare species with a relict disjunctive range - in the Republic of Altai, the Magadan Region and the Krasnoyarsk Territory.

2. Category 2 (VU), a species that is decreasing in quantity as a result of excessive human use - in the Republics of Buryatia and Sakha (Yakutia), Irkutsk Region, Khabarovsk and Trans-Baikal Territories of the Russian Federation.

The analysis of the spatial distribution of the rare relict species is important as the fundamental problem of the species' migration routes. The determination of the spatial distribution of Caragana jubata can explain features of its origin and extension.

We used collections of main herbariums in Russia (MWG, MW, LE, MHA, NS, NSK, TK) to determine the locations of Caragana jubata throughout the entire distribution of the species for species' spatial distribution mapping. In total, about 500 herbarium sheets were processed. The correct geographic coordinates of the location of the species (265 points) were identified. For georeferencing detec- tion, we used the Internet services Google Earth, as well as "Yandex maps". Some information about species locations were taken from such literary sources as: "Introduction to florae of China and Mongolia" (Komarov 1947), "Flora of the southern part of the Krasnoyarsk Territory" (Cherepnin 1963), "Woody plants of Siberia" (Koropachinskii 1983), "Features and genesis of the flora of Siberia (Baikal and Transbaikalia)" (Malyshev \& Peshkova 1984), "Ranges of trees and shrubs of the USSR" (Sokolov et al. 1986), "Unique flora objects of Central Siberia: diversity, spatial and temporal distribution, features and prospects of protection" (Boikov 2005), "Braving the attitude of altitude: Caragana jubata at work in cold desert of Himalaya" (Bhardwaj et al. 2013), "Himalayan uplift shaped biomes in Miocene temperate Asia: evidence from leguminous Caragana" (Zhang et al. 2016), et al. (Krylov 1933, Boikov 1999, Chepinoga 2009, Baritskaya 2010, Verhozina 2013, Chindyaeva \& Kiseleva 2016). In total, 68 species' occurrences were obtained from Russian and foreign articles.

From the online resource (https://www.gbif.org), which contains scientific data on biodiversity, we became information about 127 locations of our species. Data are mainly from the mountainous regions of the Himalayas and the Tibetan Plateau. There were no data about Caragana jubata on the territory of Russia at that moment (09.2018).

15 locations of Caragana jubata were added to the list by the open online atlas of plants and lichens of Russia and neighboring countries (http://www.plantarium.ru).

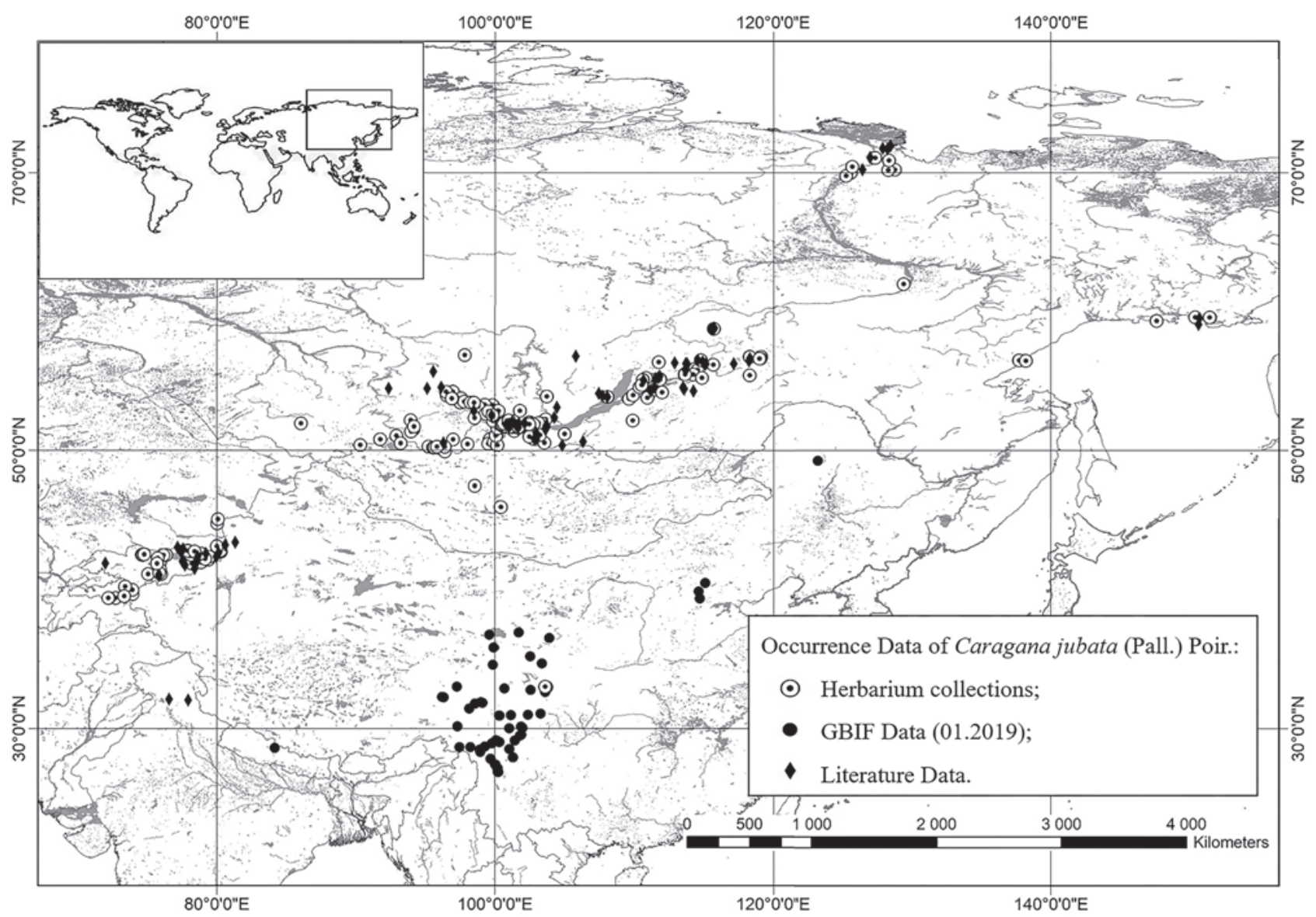

Figure 1 Distribution of Caragana jubata (Pall.) Poir. 
For species' spatial distribution mapping we used the GIS program ArcMap 10.3.1.

We composed an annotated list of locations of Caragana jubata with its correct geo-referencing. It includes information about administrative position, habitat and coenotic values of the species with reference for each. The list contains information about 475 locations of Caragana jubata for the entire area of species' distribution. The result of the distribution mapping of the species is shown in Figure 1.

We published Occurrence Data, obtained from materials of herbarium collections MW, which previously not included in the database, on the GBIF.org portal. Now they available for free public access on the Global Biodiversity Information Facility website (for example, https://www. gbif.org/occurrence/1697261003).

The spatial distribution mapping of the Caragana jubata allowed revealing a disjunctive distribution of the species' locations in nature. It associated with the history of the origin and extension of relict species (Zhang et al. 2009, Zhang \& Fritsch 2010). Having a center of origin in the Himalayas and the Tibetan Plateau, moving northward through mountain systems, this species found suitable habitats in the Tian Shan, Eastern Sayan Mountains and on the Stanovoy Range. Further north, the species appears near the Arctic coast (Kharaulakh Ridge). Some locations of Caragana jubata are on the Karaskalah Range near the Sea of Okhotsk. All enclaves of species' concentration have a mountain character of its habitats. The types of altitudinal zonation of vegetation with the presence of species are different. In the mountains of the Himalayas Caragana jubata grows in the subalpine belt (up to $4500 \mathrm{~m}$ a.s.l.) (https://www.gbif. org/occurrence/1228556080). In Central Asia mountains it occupies the sub-tundra belt (up to $2700 \mathrm{~m}$ a.s.l.) (Sokolov 1986). In the conditions of lower continental climate of the Northern Transbaikalia it has sporadic distribution on mountain taiga and sub-tundra belts (Malyshev 1972).

Disjunctions between geographic populations of the species indicate the features of the current geographical distribution of Caragana jubata, which related to the history of the mountain systems and their vegetation cover development. This species along with Potentilla salessoviana, species of genera Bieberstenia and Oreoloma demonstrate the possibilities of such connections between Central China and Central Asia regions in the early Tertiary period (previously - mid-Miocene) (Kamelin 1998). According to a considerable similarity of Caragana jubata distribution features with these species, it can be included to the group of Highland-Asia spatial distribution type. Along with that Caragana jubata has the most extensive to north direction geographical distribution. Also, ecological features are an important distinctive role. The species grows in the widest ecological amplitude of different altitudinal vegetation belts in steppe, forest, subalpine and tundra communities.

\section{ACKNOWLEDGEMENTS}

We are grateful to herbarium curators MWG, MW, LE, MHA, NS, NSK, TK for help and opportunity to work with collections. We thank A.P. Seregin for assistance in entering data in the Global Biodiversity Information Facil- ity (GBIF). The study was financially supported by Russian Science Foundation (project no. № 17-77-10142).

\section{LITERATURE CITED}

Baklanov, P.Ya. \& A.K. Tulohonov 2010. Border and crossborder territories of Asia and neighboring countries (problems and prerequisites for sustainable development), Siberian Branch RAS, Novosibirsk, 610 pp. (in Russian). [Бакланов П.Я., Тулохонов А.К. 2010. Приграничные и трансграничные территории Азиатской России и сопредемьных стран (проблемы и предпосылки устойчивого развития). Новосибирск: СО РАН, 610 с.].

Baritskaya, V.A. 2010. Caragana jubata. In: Red data Book of the Irkutsk Region (O.Yu. Gaikova ed.), p. 238, Vremya stranstvii, Irkutsk (in Russian). [Барицкая В.А. Карагана гривастая // Красная книга Иркутской области. 2010 / под. реА. О.Ю. Гайковой. Иркутск: ООО ИзАательство “Время странствий”. С. 238].

Bhardwaj, P.K., R. Kapoor., D. Mala, G. Bhagwat, V. Acharya, A.K. Singh, S.K. Vats et al. 2013. Braving the attitude of altitude: Caragana jubata at work in cold desert of Himalaya. Scientific Reports 3:1022.

Boikov, T.G. 1999. Rare plants and phytocenoses of Transbaikalia: biology, ecological geographical aspects and protection. Nauka, Novosibirsk, 265 pp. (in Russian). [Бойков Т.Г. 1999. Редкие растения и фитоценозы Забайкалья: биология, эколого-географические аспекты и охрана. Новосибирск: Наука. 265 с.].

Boikov, T.G. 2005. Unique flora objects of Central Siberia: diversity, spatial and temporal distribution, features and prospects of protection. Nauka, Novosibirsk, 181 pp. (in Russian). [Бойков Т.Г. 2005. Уникальные объекты растительного мира Центральной Сибири: разнообразие, пространственно-временное распределение, особенности и перспективы охраны. Новосибирск: Наука. 181 с.].

Chepinoga, V.V. 2009. Provisional subdivision of the Baikalian Siberia for characterization of vascular plant distribution. Izvestiya Irkutskogo gosudarstvennogo universiteta. Ser. Biologiya, ekologiya 2(2):3-7 (in Russian with English summary). [Чепинога В.В. 2009. Рабочее районирование территории Байкальской Сибири Аля характеристики распространения сосудистых растений // Известия Иркутского государственного университета. Сер. Биология, экология. Вып. 2. С. 3-7].

Cherepnin, L.M. 1963. Flora of the southern part of the Krasnoyarsk Territory, vol. 4. Krasnoyarsk, 270 pp. (in Russian). [Черепнин А.М. 1963. ФАора южной части Красноярского края. Красноярск. Вып. 4. 270 с.].

Chindyaeva, L.N. \& T.I. Kiseleva 2016. Siberian pea shrubs (Caragana Fabr.): experience of introduction and prospects of use in urban plantings in Novosibirsk. In: Problemy botaniki Yuahnoi Sibiri i Mongolii: sbornik nauchbyh statei po materialam XV Mezhdunarodnoi nauchno-prakticheskoi. konferentsii (Barnaul, May 23-26, 2016) (A.I. Shmakov \& T.M. Kopytina, eds), pp. 284-290, Concept, Barnaul (in Russian with English summary). ЧЧиндяева А.Н., Киселева Т.И. 2016. Сибирские караганы (Caragana Fabr.): опыт интродукции и перспективы использования в озеленении Новосибирска // Проблемы ботаники Южной Сибири и Монголии: сборник научных статей по материалам XV межАународной научно-практической конференции (23-26 мая 2016 г., Барнаул) / отв. реА. Шмаков А.И., Копытина Т.М. Барнаул: Концепт. С. 284-290].

GBIF Secretariat 2017. Caragana jubata Poir. in GBIF backbone taxonomy. Available from: https://www.gbif.org/species/2943329. Last accessed 19.01.2019. 
Kamelin, R.V. 1998 Materials on the history of flora of Asia (Altai Mountain Country). Altai State University, Barnaul, 240 pp. (in Russian). [Камелин Р.В. 1998. Материалы по истории флоры Азии (А^тайская горная страна). Барнаул: ИзА-во А^тайского университета. 240 с.]

Komarov, V.L. 1908. Generis Caragana monographia. Trudy Glavnogo Botanicheskogo Sada 29:179-388 (in Russian). [Koмаров В.А. 1908. Монография рода Карагана // Труды ГАавного ботанического саАа. Санкт-Петербург. Т. 29. C. 179-388].

Komarov, V.L. 1947. Introduction to flora of China and Mongolia. Izbrannye sochineniya, vol. 2. Izd-vo AN SSSR, Moscow, Leningrad. 377 pp. (in Russian). [Комаров B. А. 1947. Введение к флорам Китая и Монголии / / Избранные сочинения. Москва; Аенинград: ИзА-во АН СССР. Т. 2. 377 c.].

Koropachinskii, I.Yu. 1983. Woody plants of Siberia. Novosibirsk, 384 pp. (in Russian). [Коропачинский И.Ю. 1983. Аревесные растения Сибири. Новосибирск. 384 с.].

Krylov, P.N. 1933. Flora of Western Siberia. The manual to definition of the West Siberian plants, Rosaceae - Papilionaceae, vol. 7. Tomsk, pp. 1617-1627 (in Russian). [Крылов П.Н. 1933. Фцора Зап. Сибири. Руководство к определению западно-сибирских растений, Rosaceae - Papilionaceae. Вып. 7. Томск. С. 1617-1627].

Malyshev, L.I. (ed.) 1972 Alpine flora of the Stanovoy Highlands: composition, features and genesis. Nauka, Novosibirsk, 272 pp. (in Russian). [Высокогорная фцора Станового нагорья: состав, особенности и генезис / под реА. А.И. Малышева. Новосибирск: Наука. Сиб. отА-ние, 1972. 272 c.].

Malyshev, L.I. \& G. A. Peshkova 1984. Features and genesis of the flora of Siberia (Baikal and Transbaikalia. Nauka. Novosi- birsk, 264 pp. (in Russian). [Малышев А.И., Пешкова Г.А. 1984. Особенности и генезис фморы Сибири (ПреАбайкалье и Забайкалье). Новосибирск: Наука. 265 с.].

Plantarium 2007-2018. Open on-line atlas and key to plants and lichens of Russia and neighbouring countries. Caragana jubata Poir. in. Available from: http://www.plantarium.ru/page/view/item/8104.html. Last accessed 19.01.2019.

Sokolov, S.Ya., O.A. Svjazeva \& V.A. Kubly 1986. Ranges of trees and shrubs of the USSR, Leguminosae - Caprifoliafeae, vol. 3. Nauka, Leningrad, 181 pp. (in Russian). [Соколов С.Я., Связева О.А., Кубли В.А. 1986. Ареалы деревьев и кустарников СССР. Бобовые - Жимолостные. Том 3.

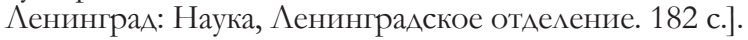

Verhozina, A.V. 2013. Caragana jubata. In: Red data Book of the Republic of Buryatia, 3rd edition, (N.M. Pronin, ed.), Buryatskiy nauchnyy tsentr SO RAN, Ulan-Ude, 688 pp. (in Russian). [Верхозина А.В. 2013. Карагана гривастая // Красная книга Республики Бурятия. ИзА. 3-е / отв. реА. Н.М. Пронин. УАан-УАэ: ИзА-во БНЦ СО РАН. 688 c.].

Zhang, M.L., P.W. Fritsch \& B.C. Cruz 2009. Phylogeny of Caragana (Fabaceae) based on DNA sequence data from $r b c \mathrm{~L}, \operatorname{trnS}-\operatorname{trn} \mathrm{G}$, and ITS. Molecular phylogenetics and evolution 50:547-559.

Zhang, M.L. \& P.W. Fritsch 2010. Evolutionary response of Caragana (Fabaceae) to Qinghai-Tibetan Plateau uplift and Asian interior aridification. Plant Systematics and Evolution 288:191-199.

Zhang, M.-L., X.-G. Xiang, J.-J. Xue, S.C. Sanderson \& P.W. Fritsch 2016. Himalayan uplift shaped biomes in Miocene temperate Asia: evidence from leguminous Caragana. Scientific Reports 6:36528. 